University of Florida Levin College of Law

UF Law Scholarship Repository

$11-2019$

\title{
The First Amendment and Speech Urging Suicide: Lessons from the Case of Michelle Carter and the Need to Expand Brandenburg's Application
}

Clay Calvert

University of Florida Levin College of Law, profclaycalvert@gmail.com

Follow this and additional works at: https://scholarship.law.ufl.edu/facultypub

Part of the Criminal Law Commons, and the First Amendment Commons

\section{Recommended Citation}

Clay Calvert, The First Amendment and Speech Urging Suicide: Lessons from the Case of Michelle Carter and the Need to Expand Brandenburg's Application, 94 Tul. L. Rev. 79 (2019)

This Article is brought to you for free and open access by the Faculty Scholarship at UF Law Scholarship Repository. It has been accepted for inclusion in UF Law Faculty Publications by an authorized administrator of UF Law Scholarship Repository. For more information, please contact kaleita@law.ufl.edu. 


\title{
The First Amendment and Speech Urging Suicide: Lessons from the Case of Michelle Carter and the Need to Expand Brandenburg's Application
}

\author{
Clay Calvert*
}

This Article examines the level of First Amendment protection that applies to a defendantspeaker when charged with involuntary manslaughter based on successfully urging a person to commit suicide. The Massachusetts Supreme Judicial Court's February 2019 decision in Commonwealth v. Carter provides a timely analytical springboard. This Article argues that courts should adopt the United States Supreme Court's test for incitement created a half-century ago in Brandenburg v. Ohio before such speech is deemed unprotected by the First Amendment. It contends this standard is appropriate even in involuntary manslaughter cases where intent to cause a specific result is not required under criminal law. This Article concludes that the Brandenburg test, which embraces a specific intent element, strikes a better balance between First Amendment interests and criminal law than does the elastic "integral to criminal conduct" standard from Giboney v. Empire Storage \& Ice Co. that the court applied in Commonwealth v. Carter. Ultimately, although Brandenburg might not have saved Michelle Carter from conviction had it been used, it could protect future defendants where demonstrating intent seems less clear-cut.

I. INTRODUCTION

II. INVOLUNTARY MANSLAUGHTER AND BRANDENBURG: A JUXTAPOSITION OF INTENT REQUIREMENTS

A. Involuntary Manslaughter in Massachusetts ................85

$B$. Incitement and the First Amendment

III. A Closer LOOK AT COMMONWEALTH V. CARTER AND THE FIRST AMENDMENT ANALYSIS: WHY BRANDENBURG IS IMPORTANT .92

IV. CONCLUSION

(C) 2019 Clay Calvert. Professor \& Brechner Eminent Scholar in Mass Communication and Director of the Marion B. Brechner First Amendment Project at the University of Florida in Gainesville, Fla. B.A., 1987, Communication, Stanford University; J.D. (Order of the Coif), 1991, McGeorge School of Law, University of the Pacific; Ph.D., 1996, Communication, Stanford University. The author thanks Olivia Baruch, Jessie Goodman, Joel Kratt, Erin McLoughlin, Carolina Panduro, Michelle Sebastian, Kevya Sims, and Emerson Tyler of the University of Florida for their helpful reviews of drafts of this Article. 


\section{INTRODUCTION}

In February 2019, the Massachusetts Supreme Judicial Court in Commonwealth v. Carter ${ }^{1}$ affirmed Michelle Carter's conviction for involuntary manslaughter ${ }^{2}$ as a youthful offender based on her urging Conrad Roy to commit suicide. ${ }^{3}$ In doing so, the court rejected Carter's claim that her conviction violated her First Amendment ${ }^{4}$ right of free speech. Specifically, it reasoned that Carter's words with Roy immediately before and while he died ${ }^{5}$ were "integral to a course of criminal conduct and thus [did] not raise any constitutional problem." ${ }^{\prime 6}$ In brief, Massachusetts's high court concluded that Carter's speech caused Roy's death ${ }^{7}$ and that the First Amendment provided her no refuge. ${ }^{8}$ Its First Amendment analysis comprises the focus of this Article, which questions whether the court applied a constitutional standard that gave short shrift to free speech concerns.

Before reaching that issue, however, it helps to understand key details about Carter. The case garnered massive attention across the

1. Commonwealth v. Carter, 115 N.E.3d 559 (Mass. 2019).

2. In Massachusetts, "[i]nvoluntary manslaughter is an unintentional, unlawful killing caused by wanton or reckless conduct." Commonwealth v. Earle, 937 N.E.2d 42, 48 (Mass. 2010). See infra Part II.A (providing an overview of involuntary manslaughter in Massachusetts).

3. Carter, 115 N.E.3d at 562.

4. The First Amendment to the U.S. Constitution provides, in relevant part, that "Congress shall make no law ... abridging the freedom of speech, or of the press." U.S. CONST. amend. I. The Free Speech and Free Press Clauses, incorporated nearly ninety-five years ago through the Fourteenth Amendment Due Process Clause as fundamental liberties, apply to state and local government entities and officials. See Gitlow v. New York, 268 U.S. 652, 666 (1925) ("[F]reedom of speech and of the press-which are protected by the First Amendment from abridgment by Congress-are among the fundamental personal rights and 'liberties' protected by the due process clause of the Fourteenth Amendment from impairment by the States.").

5. Carter, in fact, was "in voice contact while the suicide was in progress ... [and] was able to communicate with the victim, hear what was going on in the truck, and give him instructions." Carter, 115 N.E.3d at 567.

6. Id. at 572.

7. See id. at 574 ("The evidence against the defendant proved that, by her wanton or reckless conduct, she caused the victim's death by suicide.").

8. See id. at 571-72 ("[T] defendant in the instant case, or the prior involuntary manslaughter cases in the Commonwealth involving verbal criminal conduct, to suggest that the First Amendment has been violated in any way."). 
nation, ${ }^{9}$ inspiring an HBO documentary called I Love You, Now Die. ${ }^{10}$ It was likely the sensational, troubling facts surrounding the case, as well as what one newspaper aptly called its "implications for future cases about free speech and assisted suicide," that piqued such media interest. $^{11}$

In particular, Michelle Carter was seventeen years old when Conrad Roy, who was eighteen and in "fragile mental health,"12 killed himself in July 2014 by inhaling carbon monoxide in his pickup truck in Fairhaven, Massachusetts. ${ }^{13}$ The pair had maintained a long-distance relationship by texting and phone calls since meeting in 2012, although they rarely saw each other in person. ${ }^{14}$ Prior to the day Roy died, Carter had encouraged him to commit suicide, even making him promise to do so. ${ }^{15}$ Roy, in fact, tried unsuccessfully several times. ${ }^{16}$

9. See, e.g., Marco della Cava, Suicide by Text: Verdict Walks a Fine Line, USA TODAY, June 19, 2017, at 1A; Barbara Demick, Woman Guilty in Friend's Suicide, L.A. TIMES, June 17, 2017, at A5; Alanna Durkin Richer, Conviction Upheld for Woman Who Urged Boyfriend's Suicide, ST. LOUIS POST-DisPaTCH, Feb. 7, 2019, at A15; Katharine Q. Seelye, For Urging a Suicide, 15 Months in Jail, N.Y. TIMES, Aug. 4, 2017, at A10; Katharine Q. Seelye \& Jess Bidgood, Young Woman Who Urged Friend to Commit Suicide Is Found Guilty, N.Y. TIMES, June 17, 2017, at A1 1; Marie Szaniszlo \& Laurel J. Sweet, Time's up for Carter as Jail Time Begins, Bos. Herald, Feb. 12, 2019, at 5A.

10. See generally Olivia Armstrong, What to Know About 'I Love You, Now Die' Before It Premieres, HBO, https://www.hbo.com/documentaries/i-love-you-now-die-thecommonwealth-v-michelle-carter/sxsw-premiere-erin-lee-carr (last visited Oct. 24, 2019) (discussing the documentary before its premiere).

11. Barbara Demick, Is Urging One to Suicide Tantamount to Killing?, L.A. TIMES, June 16,2017 , at A6.

12. Carter, 115 N.E.3d at 562.

13. Id. at 561-62; Demick, supra note 11.

14. Carter, 115 N.E.3d at 562.

15. As the Massachusetts Supreme Judicial Court encapsulated Carter's earlier efforts to help Roy take his own life, she had:

helped plan how, where, and when he would do so, and downplayed his fears about how his suicide would affect his family. She also repeatedly chastised him for his indecision and delay, texting, for example, that he "better not be bull shiting me and saying you're gonna do this and then purposely get caught" and made him "promise" to kill himself.

Id. at 563 (footnotes omitted).

16. See id. at 562 ("Between October 2012 and July 2014, the victim attempted suicide several times by various means, including overdosing on over-the-counter medication, drowning, water poisoning, and suffocation. None of these attempts succeeded, as the victim abandoned each attempt or sought rescue."). 
Critical to Carter's conviction were two phone conversations she had with Roy immediately before and during his successful suicide on July $12,2014 .{ }^{17}$ At one point, while trying to kill himself that day, Roy left his truck and aborted his effort. ${ }^{18}$ It was what happened next that essentially sealed Michelle Carter's legal fate. Although no contemporaneous record exists of what was said during those calls, ${ }^{19}$ Carter later texted a friend stating that Roy's

death is my fault like honestly I could have stopped him I was on the phone with him and he got out of the car because it was working and he got scared and I fucking told him to get back in ... because I knew he would do it all over again the next day and I couldn't have him live the way he was living anymore I couldn't do it I wouldn't let him. ${ }^{20}$

All of this led the Massachusetts Supreme Judicial Court to conclude that Bristol County Juvenile Court Judge Lawrence Moniz, who presided over Carter's bench trial, ${ }^{21}$ reasonably could have found that Roy "was badgered back into the gas-infused truck by the defendant"22 and that Carter "did absolutely nothing to help him: she did not call for help or tell him to get out of the truck as she listened to him choke and die. ${ }^{, 23}$ Colloquially put, Carter's words were weapons that caused Roy to die in his truck, while her silence once he returned there was a fatal sin of omission.

The First Amendment, of course, does not protect all categories of expression. ${ }^{24}$ But significantly-and of key concern for this Article - the Bay State's highest court failed to apply the test for

17. See id. at 565 ("Cell phone records showed that one call of over forty minutes had been placed by the victim to the defendant, and a second call of similar length by the defendant to the victim, during the time when police believe the victim was in his truck committing suicide.").

18. See id. ("The judge found that the victim got out of the truck, seeking fresh air, in a way similar to how he had abandoned his prior suicide attempts.").

19. Id.

20. Id. (emphasis added).

21. See Seelye, supra note 9, at A10 (noting that Judge Lawrence Moniz of Bristol County Juvenile Court found Carter "guilty of involuntary manslaughter during the nonjury trial" in June 2017).

22. Carter, 115 N.E.3d at 568.

23. Id. at 568-69.

24. See Ashcroft v. Free Speech Coal., 535 U.S. 234, 245-46 (2002) ("As a general principle, the First Amendment bars the government from dictating what we see or read or speak or hear. The freedom of speech has its limits; it does not embrace certain categories of speech, including defamation, incitement, obscenity, and pornography produced with real children." (emphasis added)). 
incitement to unlawful action ${ }^{25}$ developed by the United States Supreme Court in Brandenburg $\mathcal{v}$. Ohio ${ }^{26}$ to determine if Michelle Carter's speech urging suicide fell outside the scope of constitutional protection. Brandenburg supplies the "current general test for advocacy of lawless action." ${ }^{27}$ Instead, the Massachusetts Supreme Judicial Court ruled Carter's speech was unprotected because it was "integral to a course of criminal conduct.".28 As with incitement, this is another variety of expression that the U.S. Supreme Court deems beyond the ambit of First Amendment shelter. ${ }^{29}$

This latter categorical carve-out dates back seventy years to the Court's 1949 ruling in Giboney v. Empire Storage \& Ice Co. ${ }^{30}$ In Giboney, the Court held that "it has never been deemed an abridgment of freedom of speech or press to make a course of conduct illegal merely because the conduct was in part initiated, evidenced, or carried out by means of language, either spoken, written, or printed."31

Yet, as Professor Eugene Volokh recently pointed out, this rule is "little-defined"32 and "courts need to explain and cabin its scope."

25. Suicide, although not a statutory crime in Massachusetts, conflicts with a statutory provision in that state. Specifically, Massachusetts law does not "permit any affirmative or deliberate act to end one's own life other than to permit the natural process of dying." MASS. GEN. LAWS ch. 201D, §12 (2019) (emphasis added). Under this statute, Massachusetts is "implicitly declaring that suicide is illegal." Katherine Ann Wingfield \& Carl S. Hacker, Physician-Assisted Suicide: An Assessment and Comparison of Statutory Approaches Among the States, 32 SeTON HALl LEGIS. J. 13, 57 (2007). Historically, however, suicide was a common law crime in the Bay State. See Commonwealth v. Mink, 123 Mass. 422, 425 (1877) ("The life of every human being is under the protection of the law, and cannot be lawfully taken by himself, or by another with his consent, except by legal authority." (emphasis added)).

26. 395 U.S. 444, 447 (1969).

27. S. Elizabeth Wilborn Malloy \& Ronald J. Krotoszynski Jr., Recalibrating the Cost of Harm Advocacy: Getting Beyond Brandenburg, 41 WM. \& MARY L. REV. 1159, 1192 (2000).

28. Carter, 115 N.E.3d at 572 .

29. See United States v. Alvarez, 567 U.S. 709, 717 (2012) (identifying "speech integral to criminal conduct" as among the categories of expression not protected by the First Amendment); United States v. Stevens, 559 U.S. 460, 468 (2010) (listing "speech integral to criminal conduct" as a category of unprotected speech).

30. 336 U.S. 490, 502 (1949). In Giboney, the Court rejected the contention that "the constitutional freedom for speech and press extends its immunity to speech or writing used as an integral part of conduct in violation of a valid criminal statute." Id. at 498. The Court added that "it has never been deemed an abridgment of freedom of speech or press to make a course of conduct illegal merely because the conduct was in part initiated, evidenced, or carried out by means of language, either spoken, written, or printed." Id. at 502 .

31. Id.

32. Eugene Volokh, The "Speech Integral to Criminal Conduct" Exception, 101 CORNELl L. REV. 981, 983 (2016).

33. Id. at 984 . 
Similarly, Professor Michal Buchhandler-Raphael notes that while the U.S. Supreme Court has recently listed the integral-to-criminalconduct exception among the varieties of unprotected speech, it has failed to articulate "guidelines on the scope of the exception." ${ }^{34}$ In brief, it is highly problematic to apply such a nebulous standard when a person's freedom from incarceration lies in the balance.

Furthermore, the speech at issue in Giboney had nothing to do with an individual urging another person to commit a specific act like killing himself. ${ }^{35}$ Rather, the expression in Giboney constituted picketing by a labor union at a company's place of business. ${ }^{36}$ The picketing, in turn, was part of a larger plan by the union to force the business to violate a state antitrust statute. ${ }^{37}$ Such speech is, factually, far removed from one teen urging another to kill himself.

Yet, for the Massachusetts Supreme Judicial Court, Carter was not a Brandenburg case about speech urging someone to commit an unlawful act imminently. Rather, it was a case about the words themselves, much like bullets shot from a gun, causing the crime of involuntary manslaughter and, therefore, under Giboney, not insulated by the First Amendment.

This Article examines whether this analysis by Massachusetts's highest court is correct. Part II initially provides an overview of the crime of involuntary manslaughter in Massachusetts and then briefly describes the Massachusetts Supreme Judicial Court's analysis of the wanton-or-reckless conduct facet of that crime in Commonwealth $v$. Carter. ${ }^{38}$ Furthermore, Part II reviews the U.S. Supreme Court's incitement standard from Brandenburg and contends that it should apply to cases such as Carter where, although the underlying act of suicide itself may be lawful, ${ }^{39}$ a defendant's words become their very own crime for supposedly causing it. Next, Part III argues that the Brandenburg test should have applied in Carter, particularly in light of Brandenburg's intent requirement. ${ }^{40}$ Finally, this Article concludes in Part IV by suggesting that although the Brandenburg test might not

34. Michal Buchhandler-Raphael, Overcriminalizing Speech, 36 CARDOZO L. REV. $1667,1708-09$ (2015).

35. See Giboney, 336 U.S. at 491-92.

36. Id. at $497-500$.

37. Id. at 501-04.

38. See infra notes 42-84 and accompanying text.

39. See Penney Lewis, Rights Discourse and Assisted Suicide, 27 AM. J.L. \& MED. 45, 59 n.76 (2001) ("Suicide is no longer a crime in any American state.").

40. Infra notes 85-106 and accompanying text. 
have saved Michelle Carter from conviction, it may help other defendants where the question of intent is seemingly more speculative. $^{41}$

\section{INVOLUNTARY MANSLAUGHTER AND BRANDENBURG: A JUXTAPOSITION OF INTENT REQUIREMENTS}

This Part has two subparts. Subpart A provides a primer on the crime of involuntary manslaughter in Massachusetts. Subpart B then offers an overview of the U.S. Supreme Court's incitement doctrine as defined in its fifty-year-old Brandenburg v. Ohio ruling. Subpart B also argues that Brandenburg should extend to cases where, although the underlying act (suicide, in Carter) is lawful itself, the words that successfully urge it to completion become their own crime.

\section{A. Involuntary Manslaughter in Massachusetts}

Involuntary manslaughter, like murder, is a type of homicide. ${ }^{42} \mathrm{~A}$ key distinction between murder and manslaughter, however, is that the latter only arises in the absence of malice. ${ }^{43}$ Massachusetts defines involuntary manslaughter under its common law, rather than by statute. $^{44}$ Specifically, "[i]nvoluntary manslaughter is an unlawful homicide unintentionally caused by an act which constitutes such a disregard of probable harmful consequences to another as to amount to wanton or reckless conduct." 45 More succinctly, involuntary manslaughter is "an unintentional, unlawful killing caused by wanton or reckless conduct." ${ }^{" 46}$ What does this mean?

First, "[w]anton or reckless conduct generally involves a willful act that is undertaken in disregard of the probable harm to others that

41. Infra notes 107-114 and accompanying text.

42. See Carol S. Steiker, Justice vs. Mercy in the Law of Homicide: The Contest Between Rule-of-Law Values and Discretionary Leniency from Common Law to Codification to Constitution, 47 TEX. TECH L. REV. 1, 2 (2014) ("The common-law categories of murder, voluntary manslaughter, and involuntary manslaughter (or rough statutory equivalents with different appellations) cover most homicides, while modern Anglo-American legislatures today maintain separate statutory treatment for only a few special categories of homicide such as vehicular homicide and euthanasia.").

43. Commonwealth v. Pagan, 31 N.E.3d 575, 583 (Mass. 2015).

44. See Commonwealth v. Levesque, 766 N.E.2d 50, 55 (Mass. 2002) ("Because Massachusetts has not defined manslaughter by statute, its elements are derived from the common law.").

45. Commonwealth v. Vanderpool, 328 N.E.2d 833, 836 (Mass. 1975).

46. Commonwealth v. Earle, 937 N.E.2d 42, 48 (Mass. 2010). 
may result." ${ }^{, 47}$ Put slightly differently, wanton or reckless conduct means intentional conduct that "involves a high degree of likelihood that substantial harm will result to another." ${ }^{, 48}$

Whether actions are wanton or reckless is "determined based either on the defendant's specific knowledge or on what a reasonable person should have known in the circumstances. ${ }^{.49}$ The first facet of this disjunctive test is subjective, focusing on the defendant's state of mind, while the second facet is an objective measure, focusing on what "a reasonable person in the defendant's circumstances would have perceived." 50 In other words, "a defendant's subjective awareness of the reckless nature of his conduct is sufficient, but not necessary, to convict him of involuntary manslaughter. Conduct which a reasonable person, in similar circumstances, would recognize as reckless will suffice as well." ${ }^{51}$ Failing to act where such a duty exists may also be wanton or reckless conduct. ${ }^{52}$

Second - and importantly for purposes of this Article - "reckless conduct does not require that the actor intend the specific result of his or her conduct, but only that he or she intended to do the reckless act." 53 This is important because, as the next subpart illustrates, the U.S. Supreme Court's test for incitement to unlawful action adopted in Brandenburg demands proof that a speaker intended the resulting conduct to occur before her speech falls outside of First Amendment protection. ${ }^{54}$

In brief, there is a disconnect on intent between Massachusetts's law and the First Amendment. Under Massachusetts's definition of involuntary manslaughter, intent for the result to occur is not required. ${ }^{55}$ The U.S. Supreme Court's definition of incitement, however, requires

47. Commonwealth v. Life Care Ctrs. of Am., Inc., 926 N.E.2d 206, 211 (Mass. 2010).

48. Commonwealth v. Welansky, 55 N.E.2d 902, 910 (Mass. 1944).

49. Commonwealth v. Pugh, 969 N.E.2d 672, 685 (Mass. 2012) (emphasis added).

50. Commonwealth v. Moore, 82 N.E.3d 1043, 1049 (Mass. App. Ct. 2015).

51. Commonwealth v. Catalina, 556 N.E.2d 973, 979 (Mass. 1990).

52. See Commonwealth v. Twitchell, 617 N.E.2d 609, 613 (Mass. 1993) (“A charge of involuntary manslaughter based on an omission to act can be proved only if the defendant had a duty to act and did not do so."); Welansky, 55 N.E.2d at 910 ("The essence of wanton or reckless conduct is intentional conduct, by way either of commission or of omission where there is a duty to act, which conduct involves a high degree of likelihood that substantial harm will result to another." (emphasis added)).

53. Commonwealth v. Life Care Ctrs. of Am., Inc., 926 N.E.2d 206, 211 (Mass. 2010) (emphasis added).

54. Brandenburg v. Ohio, 395 U.S. 444, 448-49 (1969).

55. Commonwealth v. Carter, 115 N.E.3d 559, 569 (Mass. 2019). 
an intent to bring about a specific result for the speech to be unprotected. $^{56}$

Adding a Brandenburg layer of First Amendment defense in cases such as Carter, as this Article calls for in Part III, thus has the practical effect of transforming involuntary manslaughter into a specific intent crime. ${ }^{57}$ In other words, by incorporating Brandenburg into the equation, Michelle Carter must have both intended to make the statements that she communicated to Conrad Roy (the only intent requirement for involuntary manslaughter) and intended them to bring about the harmful consequence of Conrad Roy committing suicide. More succinctly, the court could convict Carter only if she intended to make the statements and only if she made them with the purpose of having Roy kill himself.

The Massachusetts Supreme Judicial Court, however, did not consider this proposed and additional constitutional hurdle in Commonwealth v. Carter. It only considered if the statements Michelle Carter intended to make (and, in fact, did make) were wanton or reckless. The court concluded there was "no doubt ... that the defendant wantonly or recklessly instructed the victim to kill himself, and that her instructions caused his death. ${ }^{.58}$ Significantly, it reasoned that wanton or reckless conduct included not only physical conduct but also "verbal conduct," thereby blurring in criminal law what is a traditional dichotomy in First Amendment jurisprudence between speech and conduct. ${ }^{60}$ In affirming the juvenile court judge's

56. Nwanguma v. Trump, 903 F.3d 604, 609 (6th Cir. 2018) (citing Bible Believers v. Wayne Cty., 805 F.3d 228, 246 (6th Cir. 2015)).

57. Heidi M. Hurd \& Michael S. Moore, Punishing Hatred and Prejudice, 56 STAN. L. REV. 1081, 1121 (2004) ("A specific intent crime is a crime that requires a defendant to do a prohibited action with some further purpose (beyond the purpose to do the prohibited act)." (emphasis omitted)); Eric A. Johnson, Rethinking the Presumption of Mens Rea, 47 WAKE FOREST L. REV. 769, 791 (2012) (observing that courts typically define a general-intent crime as one that "requires the government to prove only that "the defendant intended to do the proscribed act," "while a specific-intent crime is one that "requires the government to prove that the defendant also intended to 'achieve some additional consequence"' (quoting People v. Hood, 462 P.2d 370, 378 (Cal. 1969))).

58. Carter, 115 N.E.3d at 569.

59. Id. at 570 (emphasis added).

60. See generally Diahann DaSilva, Playing a "Labeling Game": Classifying Expression as Conduct as a Means of Circumventing First Amendment Analysis, 56 B.C. L. REV. 767, 769-70 (2015) (observing "the speech versus conduct dichotomy," and analyzing "the distinction between speech and conduct, the implications of that distinction, and how courts have classified various activities as speech or conduct"); Paul Sherman, Occupational Speech and the First Amendment, 128 HARV. L. REV. F. 183, 188 (2015) ("The notion that 
determination that Michelle Carter acted wantonly and recklessly, the Massachusetts Supreme Judicial Court reasoned:

[T]he judge expressly tracked the elements of manslaughter. He found: "She instructs [the victim] to get back into the truck, well knowing of all of the feelings that he has exchanged with her-his ambiguities, his fears, his concerns." This, the judge found, constituted "wanton and reckless conduct by [the defendant], creating a situation where there is a high degree of likelihood that substantial harm would result to [the victim]. ${ }^{.61}$

In brief, the judge focused on the final moments before Conrad Roy killed himself and, in particular, the knowledge that Michelle Carter had at that time about Roy's mental state, his physical state, his location, and the toxic air inside the truck. ${ }^{62}$ It was Carter's knowledge about those circumstances, coupled both with her instructions for Roy to get back in his truck and her failure to take any steps to stop him once inside, that the judge determined tantamount to wanton or reckless conduct. $^{63}$ The formula, as it were, was the following: knowledge + instructions + failure to act $=$ wanton or reckless conduct .

Proving intent to cause harm thus was not an issue for involuntary manslaughter; all that mattered was Carter's "wanton or reckless pressuring of a vulnerable person to commit suicide. ${ }^{.64}$ As the next subpart illustrates, however, the First Amendment incitement test requires proof of intent when an individual advocates that another person commit an unlawful act.

there is a distinction between laws that regulate speech and laws that regulate conduct with merely an incidental effect on speech is well established.").

61. Carter, 115 N.E.3d at 567 (quoting Judge Lawrence Moniz, FOX 10 Phoenix, MUST WATCH: Judge Finds Michelle Carter GUILTY in Texting Suicide Case in Massachusetts, YOUTUBE (June 16, 2017), https://www.youtube.com/watch? $\mathrm{v}=1$ wkyxXeOC0k).

62. Id. at 565.

63. The court explained:

The judge found that when the defendant realized he had gotten out of the truck, she instructed him to get back in, knowing that it had become a toxic environment and knowing the victim's fears, doubts, and fragile mental state. The victim followed that instruction. Thereafter, the defendant, knowing the victim was inside the truck and that the water pump was operating-the judge noted that she could hear the sound of the pump and the victim's coughing-took no steps to save him. She did not call emergency personnel, contact the victim's family, or instruct him to get out of the truck. The victim remained in the truck and succumbed to the carbon monoxide. The judge concluded that the defendant's actions and her failure to act constituted, "each and all," wanton and reckless conduct that caused the victim's death.

Id. (emphasis added) (internal footnote omitted) (quoting Moniz, supra note 61).

64. Id. at 572 . 


\section{B. Incitement and the First Amendment}

In Brandenburg v. Ohio, ${ }^{65}$ the U.S. Supreme Court held that the First Amendment does "not permit a State to forbid or proscribe advocacy of the use of force or of law violation except where such advocacy is directed to inciting or producing imminent lawless action and is likely to incite or produce such action." ${ }^{66}$ The three core elements of this test are the following: (1) intent, (2) imminence, and (3) likelihood. ${ }^{67}$

The Brandenburg test, as Professor Margot Kaminski notes, resolved-at least for now-the Court's long struggle to address "whether and how to protect speech that calls to action." ${ }^{\prime 68}$ It replaced the Court's clear-and-present-danger standard ${ }^{69}$ developed in Schenck v. United States. ${ }^{70}$

Brandenburg, as Part III argues, thus should be relevant in cases such as Commonwealth v. Carter where the defendant's speech urges another person to commit an act and either:

- when the resulting act committed by that other person is unlawful or

- when a court engages in the legal fiction that words urging action that another person follows to completion are themselves the speaker's own crime (that Michelle Carter committed involuntary manslaughter with her words, not deeds).

65. 395 U.S. 444 (1969).

66. Id. at 447 .

67. Rodney A. Smolla, Should the Brandenburg v. Ohio Incitement Test Apply in Media Violence Tort Cases?, 27 N. KY. L. REV. 1, 10 (2000) (asserting that the Brandenburg test appears "to contain three constituent elements: (1) intent (embodied in the requirement that such speech to be 'directed to inciting or producing' lawless action); (2) imminence (embodied in the phrase 'imminent lawless action'); and (3) likelihood (embodied in the phrase 'and is likely to incite or produce such action')" (quoting Brandenburg, 395 U.S. at 447)).

68. Margot Kaminski, Incitement to Riot in the Age of Flash Mobs, 81 U. CIN. L. REV. 1,40 (2012).

69. See Susan M. Gilles, Brandenburg v. State of Ohio: An "Accidental," "Too Easy," and "Incomplete" Landmark Case, 38 CAP. U. L. REV. 517, 520 (2010) ("Brandenburg is famous for abandoning the 'clear and present danger' test.").

70. 249 U.S. 47, 52 (1919). In Schenck, the Court held that whether the First Amendment protects speech urging unlawful action depends on "whether the words used are used in such circumstances and are of such a nature as to create a clear and present danger that they will bring about the substantive evils that Congress has a right to prevent." $I d$. 
Because suicide itself is lawful, though not permitted, in the United States, ${ }^{71}$ the first facet (the one confined to a literal reading of Brandenburg's "lawless action"72 requirement) does not apply in a case such as Commonwealth v. Carter. The second facet, in contrast, represents an expansion of Brandenburg that would sweep up Carter.

In other words, Brandenburg's three-factor test (intent, imminence, and likelihood) should be expanded and applied where speech urges others to commit acts that are unlawful, as well as in cases where conduct-urging speech is itself deemed criminal because another person followed it. Adding this second facet, as Part III argues, is important because it incorporates a layer of First Amendment protection into criminal cases hinging on conduct-urging speech such as Carter. This addition would be similar to the way that the U.S. Supreme Court has held that a veneer of First Amendment safety is essential to add in some instances in tort law when speech allegedly causes reputational harm or emotional distress. ${ }^{73}$ In fact, the Court extended the actual malice standard that applies in such tort cases as a

71. See Kent Greenawalt, Objections in Conscience to Medical Procedures: Does Religion Make a Difference?, 2006 U. ILL. L. REV. 799, 804 n.23 ("[S]uicide is no longer a crime ....").

72. Brandenburg, 395 U.S. at 447.

73. For instance, the U.S. Supreme Court has adopted the actual malice standard to provide First Amendment protection in libel cases where the plaintiff is a public official or public figure and in intentional infliction of emotional distress cases where the plaintiff is a public official or public figure suing over speech. See Hustler Magazine, Inc. v. Falwell, 485 U.S. 46, 56 (1988) (involving a lawsuit for intentional infliction of emotional distress based upon offensive speech in a parody of a magazine advertisement, and concluding that "public figures and public officials may not recover for the tort of intentional infliction of emotional distress by reason of publications such as the one here at issue without showing in addition that the publication contains a false statement of fact which was made with 'actual malice"'); Curtis Publ'g Co. v. Butts, 388 U.S. 130, 155-56 (1967) (extending the actual malice standard to libel cases brought by public figures); N.Y. Times Co. v. Sullivan, 376 U.S. 254, 279-80 (1964) (concluding that the First Amendment requires "a federal rule that prohibits a public official from recovering damages for a defamatory falsehood relating to his official conduct unless he proves that the statement was made with "actual malice"'). Additionally, the court has held that if a private person sues for intentional infliction of emotional distress based upon speech, the defendant has protection against tort liability if the speech is about a matter of public concern. See Snyder v. Phelps, 562 U.S. 443, 451, 460 (2011) (reasoning that "[w] hether the First Amendment prohibits holding [defendant] Westboro [Baptist Church] liable for its speech in this case turns largely on whether that speech is of public or private concern, as determined by all the circumstances of the case," and concluding that the defendant's speech was protected from tort liability because it "addressed matters of public import on public property, in a peaceful manner, in full compliance with the guidance of local officials"). 
First Amendment shield to apply to criminal law in criminal libel cases. ${ }^{74}$

Before turning to that argument in detail in the next Part, however, it is critical to understand that Brandenburg requires that speech be "intended to produce"75 unlawful action before it falls outside of First Amendment protection. ${ }^{76}$ As the U.S. Supreme Court interpreted Brandenburg four years later in Hess $v$. Indiana, there must be evidence that the speaker's words "were intended to produce, and likely to produce, imminent disorder" before a state may permissibly punish the speaker. ${ }^{77}$ Put slightly differently, the message must be "intended by the speaker to instigate" ${ }^{78}$ such action. ${ }^{79}$ Or, as Professor Steven Gey encapsulated it in 2010, Brandenburg "allows the government to prosecute only those who intend through their expression to cause harm. ${ }^{.80}$

The United States Court of Appeals for the Sixth Circuit reaffirmed this intent requirement in 2018 in Nwanguma $v$. Trump.$^{81}$ It considered in Nwanguma whether Donald J. Trump's words at a presidential campaign rally in 2016 that allegedly triggered an assault on several protestors constituted an unlawful incitement under Brandenburg. ${ }^{82}$ In concluding that Trump's speech was protected by the First Amendment, the Sixth Circuit observed: "The Brandenburg test precludes speech from being sanctioned as incitement to riot

74. Garrison v. Louisiana, 379 U.S. 64, 74 (1964) ("The reasons which led us so to hold in New York Times ... apply with no less force merely because the remedy is criminal. The constitutional guarantees of freedom of expression compel application of the same standard to the criminal remedy." (internal citation omitted)).

75. Hess v. Indiana, 414 U.S. 105, 109 (1973).

76. See Michael Vitiello, The Nuremberg Files: Testing the Outer Limits of the First Amendment, 61 OHо ST. L.J. 1175, 1217 (2000) ("'A] state must prove the speaker's intent to bring about the harm; the Court will read ambiguous evidence of the speaker's intent in favor of the speaker. The Court requires intent, not mere knowledge, that the harm will occur.").

77. Hess, 414 U.S. at 109 (emphasis omitted).

78. Steven G. Gey, The Nuremberg Files and the First Amendment Value of Threats, 78 TEX. L. REV. 541 , 547 (2000).

79. See Robert Firester \& Kendall T. Jones, Catchin' the Heat of the Beat: First Amendment Analysis of Music Claimed to Incite Violent Behavior, 20 LOY. L.A. ENT. L. REV. 1, 7-8 (2000) ("[Brandenburg] require[s] some showing of intent, whether explicit or implicit, in conjunction with the other requirements of the test in order to justify revocation of First Amendment protection.").

80. Steven G. Gey, The Brandenburg Paradigm and Other First Amendments, $12 \mathrm{U}$. PA. J. Const. L. 971, 977-78 (2010).

81. 903 F.3d 604, 609 (6th Cir. 2018).

82. See id. at 607-09. 
unless ... the speaker intends that his speech will result in the use of violence or lawless action...."

Thus, had a Brandenburg analysis been undertaken in Commonwealth v. Carter to give Michelle Carter a layer of possible First Amendment protection from criminal punishment, Massachusetts would have needed to prove that she actually intended for Conrad Roy to kill himself. A finding that she merely acted recklessly or wantonly-all that is necessary for involuntary manslaughter ${ }^{84}$ would have been insufficient. This next Part argues that such a First Amendment-based Brandenburg buffer is important in involuntary manslaughter cases based on speech urging suicide.

\section{A Closer LoOK AT COMMONWEALTH V. CARTER AND THE FIRST AMENDMENT ANALYSIS: WHY BRANDENBURG IS IMPORTANT}

As explained in the Introduction, ${ }^{85}$ the Massachusetts Supreme Judicial Court did not consider Brandenburg v. Ohio and, instead, only applied the U.S. Supreme Court's standard from Giboney v. Empire Storage \& Ice Co. to determine if the First Amendment provided Michelle Carter with any defense. ${ }^{86}$ That is troublesome because Giboney's integral-to-criminal-conduct test, also described earlier, ${ }^{87}$ offers no additional layer of First Amendment protection at all in cases such as Commonwealth v. Carter. This poorly defined standard ${ }^{88}$ holds merely that if speech is integral to criminal conduct, then it receives no constitutional protection. In brief, if the defendant's words are, as the Giboney Court put it, "an essential and inseparable part of a grave offense," ${ }^{, 89}$ then the First Amendment is no longer relevant.

The Massachusetts Supreme Judicial Court held that Giboney applied in Carter.$^{90}$ First, it reasoned that the criminal conduct at issue was involuntary manslaughter. ${ }^{91}$ Second, Michelle Carter's words were

83. Id. at 609 (emphasis added) (quoting Bible Believers v. Wayne Cty., 805 F.3d 228, 246 (6th Cir. 2015) (en banc)).

84. See supra notes 47-53 and accompanying text (addressing the wanton-or-reckless conduct element).

85. See supra notes $25-27$ and accompanying text.

86. See discussion supra Part I.

87. See supra notes 28-37 and accompanying text.

88. See supra notes $32-34$ and accompanying text.

89. Giboney v. Empire Storage \& Ice Co., 336 U.S. 490, 502 (1949).

90. Commonwealth v. Carter, 115 N.E.3d 559, 570-71 (Mass. 2019).

91. See id. at $\mathbf{5 7 0 ~ ( " T h e ~ c r i m e ~ o f ~ i n v o l u n t a r y ~ m a n s l a u g h t e r ~ p r o s c r i b e s ~ r e c k l e s s ~ o r ~}$ wanton conduct causing the death of another." (emphasis added)). 
integral to that criminal conduct because they were uttered wantonly and recklessly - an essential element of involuntary manslaughter ${ }^{22}$ and because they triggered a person's death, another essential ingredient of involuntary manslaughter, ${ }^{93}$ thereby extinguishing any First Amendment concerns. ${ }^{94}$ In other words, if a court identifies a particular crime - here, involuntary manslaughter - and the speech at issue satisfies integral elements of that crime, then free expression concerns evaporate.

Brandenburg, in contrast, would have forced the prosecution to clear three different hurdles in addition to the elements of involuntary manslaughter before discharging First Amendment concerns from the criminal equation. Specifically, and as applied to Michelle Carter's case, it would have required the prosecution to prove that (1) Michelle Carter intended for Conrad Roy to take his own life; (2) the time between Carter's words and Roy's suicide was very short (Brandenburg's imminence prong); and (3) it was likely Roy would, in fact, commit suicide after hearing Carter's words (Brandenburg's likelihood prong). This is not, by any means, an absolute First Amendment defense. It may well have been that the prosecution could have satisfied all three elements in Michelle Carter's case. However, unlike Giboney, Brandenburg at least mandates that the government satisfy a trio of clear and distinct elements before removing First Amendment concerns from the prosecutorial table. ${ }^{95}$

Why is it important to apply the Brandenburg test as a First Amendment layer of protection in involuntary manslaughter cases like

92. See supra notes $46-52$ and accompanying text (addressing the wanton-or-reckless conduct element).

93. See Carter, 115 N.E.3d at 569 ("It has long been established in our common law that wanton or reckless conduct that causes a person's death constitutes involuntary manslaughter." (emphasis added)).

94. Summing up this line of analysis, the Massachusetts Supreme Judicial Court reasoned that:

The only verbal conduct punished as involuntary manslaughter has been the wanton or reckless pressuring of a vulnerable person to commit suicide, overpowering that person's will to live and resulting in that person's death. We are therefore not punishing words alone, as the defendant claims, but reckless or wanton words causing death. The speech at issue is thus integral to a course of criminal conduct and thus does not raise any constitutional problem.

Id. at 572 .

95. Compare Brandenburg v. Ohio, 395 U.S. 444, 447 (1969), and Rodney A. Smolla, Should the Brandenburg v. Ohio Incitement Test Apply in Media Violence Tort Cases?, $27 \mathrm{~N}$. KY. L. REV. 1, 10 (2000), with Giboney v. Empire Storage \& Ice Co., 336 U.S. 490, 498, 502 (1949). 
Carter? The answer is that if a court is going to engage in the twin fictions that a person's words constitute conduct ${ }^{96}$ and that they are so powerful and tremendously forceful as to actually cause a death, as the Massachusetts Supreme Judicial Court believed, ${ }^{97}$ then it must balance out such assumptions about the lethal power of speech with First Amendment safeguards. Those assumptions about speech are akin to the outdated hypodermic needle or bullet theory of powerful effects of media messages on audience members. ${ }^{98}$

Ironically, Massachusetts's highest court readily acknowledged in Carter "that legal causation in the context of suicide is an incredibly complex inquiry." "9 Others have also noted the complexity of establishing causation in suicide cases like Carter. ${ }^{100}$ Countering conclusions about causation with a First Amendment intent requirement like that in Brandenburg thus provides a necessary balance on the defendant's behalf.

The decision in Carter that words can kill represents, as attorney Matthew Segal of ACLU Massachusetts put it, "a drastic expansion of criminal law in Massachusetts." 101 Indeed, Robert Cordy, a justice on the Massachusetts Supreme Judicial Court, acknowledged that Commonwealth v. Carter was precedent setting as the first case in the Bay State in which words, standing alone, formed the basis for involuntary manslaughter. ${ }^{102}$ The decision also vitiates the general legal principle, as Professor Sharon Beckman explains, "that a person is responsible for their own suicide. That ... applies no matter what the other person said or whether they handed them the weapon." 103

96. The court used the phrase "verbal conduct" more than a half-dozen times to refer to Michelle Carter's words. Carter, 115 N.E.3d at 562-72.

97. See id. at 569 (concluding that Carter's "instructions caused his death").

98. See generally JENNINGS BRYANT \& SUSAN THOMPSON, FUNDAMENTALS OF MEDIA EFFECTS 36-37 (2002) (addressing this theory).

99. Carter, 115 N.E.3d at 568.

100. See, e.g., Nicholas LaPalme, Note, Michelle Carter and the Curious Case of Causation: How to Respond to a Newly Emerging Class of Suicide-Related Proceedings, 98 B.U. L. REV. 1443, 1446 (2018) ("[E]stablishing causation in encouraging suicide cases, such as Michelle Carter's case, involves a higher degree of complexity that cannot be overlooked.").

101. Seelye \& Bidgood, supra note 9, at A11.

102. See Jess Bidgood, Text to Teenager Before His Suicide: 'You've Gotta Do It,' N.Y. TIMES, June 7, 2017, at A12 ("Robert Cordy, a Supreme Judicial Court justice, acknowledged that Ms. Carter's case was the first involuntary manslaughter indictment the court had considered 'on the basis of words alone."' (quoting Commonwealth v. Carter, 52 N.E.3d 1054, 1062 (Mass. 2016)).

103. Demick, supra note 11, at A6. 
Caution must accompany such a vast expansion of involuntary manslaughter from the realm of physical conduct into the domain of expression, especially because Carter involved rarely trodden, if not completely uncharted, legal territory. ${ }^{104}$ By definition, the case puts into play concerns about speech, which in turn puts the First Amendment at issue. Brandenburg provides a measure of limited protection in these situations to prevent the needless trampling on First Amendment speech interests. Its application allows for conviction but requires proof of an intent - a specific purpose - to cause a suicide (along with proof of imminence and likelihood of suicide) before such a conviction can be upheld.

Carter rests on the belief that words actually kill. That simply is not accurate. As Professor Mary Anne Franks observes, "[Carter's] words caused great harm, but they didn't kill this young man. He chose to kill himself ...."105 Kathleen Parker echoed this sentiment about Carter's speech in the Washington Post, remarking, "Words do matter, but they're not lethal."106 Nevertheless, if courts are to engage in such fiction, they should at least apply Brandenburg to balance out First Amendment concerns. In brief, if expanding upon involuntary manslaughter to punish a defendant whose speech encourages it, then Brandenburg should apply to allow a possible defense for such defendants.

\section{CONCLUSION}

The First Amendment may not have protected Michelle Carter's words, which led to her involuntary manslaughter conviction, even if the Massachusetts Supreme Judicial Court had applied Brandenburg's incitement standard instead of Giboney's integral-to-criminal-conduct test. Given Carter's text to a friend, stating that she told Conrad Roy to get back in his truck after he initially left it, ${ }^{107}$ and given indications

104. Professors Guyora Binder and Luis Chiesa explain that:

homicide liability for the suicide of another is rare, and almost always involves some more tangible contribution to the killing than Carter's. Indeed, we have found no previous American case where the victim intentionally killed himself and the defendant was convicted of homicide for verbal encouragement only. Nor have we found another case of homicide liability where the encourager was never in the presence of the suicide.

Guyora Binder \& Luis Chiesa, The Puzzle of Inciting Suicide, 56 AM. CRIM. L. REV. 65, 66 (2019) (internal footnote omitted).

105. della Cava, supra note 9, at 1A.

106. Kathleen Parker, Can Words Kill?, WASH. Post, June 21, 2017, at A17.

107. Commonwealth v. Carter, 115 N.E.3d 559, 565 (Mass. 2019). 
from another text that she did nothing to stop Roy from killing himself once he got back in his truck and she heard him dying, ${ }^{108}$ a reasonable factfinder, whether a judge or a jury, might come to the conclusion that Carter intended for Roy to kill himself. The imminence and likelihood elements of Brandenburg might also have been met in Commonwealth v. Carter, given that Carter was talking with Roy immediately before he died (satisfying imminence) and given Roy's mental state and prior suicide efforts (perhaps suggesting a likelihood that he would kill himself).

In future cases, however, proving intent and the other two Brandenburg elements may not be so seemingly easy or certain. The line, in turn, between protected advocacy and unprotected incitement may be blurrier. In fact, the abstract advocacy of suicide merits First Amendment protection. As the Minnesota Supreme Court wrote in 2014, "Speech in support of suicide, however distasteful, is an expression of a viewpoint on a matter of public concern, and, given current U.S. Supreme Court First Amendment jurisprudence, is therefore entitled to special protection as the 'highest rung of the hierarchy of First Amendment values." "109

In summary, expanding the scope of Brandenburg beyond those situations in which the act urged is unlawful (given that suicide today is generally considered lawful ${ }^{10}$ ) to reach cases in which the words urging conduct themselves become the unlawful act is essential. Specifically, it is imperative to protect the First Amendment speech interests of defendants in involuntary manslaughter cases such as Commonwealth v. Carter where a court treats words like conduct and engages in assumptions about the powerful effects of speech on individuals.

Such cases, in fact, may become more common. That is because "suicide is the second-leading cause of death among people between the ages of 10 and 24"111 - Conrad Roy, in fact, was just eighteen years old when he took his own life ${ }^{12}$ - and bullying is a pervasive behavior

108. Id.

109. State v. Melchert-Dinkel, 844 N.W.2d 13, 24 (Minn. 2014) (quoting Snyder v. Phelps, 562 U.S. 443, 444 (2011)).

110. See Carla Zavala, Comment, Manslaughter by Text: Is Encouraging Suicide Manslaughter?, 47 SETON HALL L. REV. 297, 307 (2016) ("Faced with an inability to punish the crime, many states decided not to treat suicide as a crime at all when they moved away from the common law and shifted toward statutory crimes.").

111. Alex B. Long, Abolishing the Suicide Rule, 113 Nw. U. L. REV. 767, 768 (2018).

112. See supra notes $12-13$ and accompanying text. 
among teens. ${ }^{113}$ Furthermore, lawmakers in some states, in reaction to Michelle Carter's case, are now proposing legislation that would make it a crime to "encourage" suicide. ${ }^{114}$ If, and when, such new cases come down the legal pike, future defendants must be able to mount a Brandenburg defense rather than lose all First Amendment protection under Giboney.

113. See U.S. DeP'T OF EduC., NCES 2017-015, STUdENT REPORTS OF BULlYING: RESUlTS FROM THE 2015 SCHOOL CRIME SUPPLEMENT TO THE NATIONAL CRIME VICTIMIZATION SURVEY, at T-1 (2016), https://nces.ed.gov/pubs2017/2017015.pdf (noting that $20.8 \%$ of students surveyed, who ranged in ages from twelve to eighteen years, reported being bullied at school during the 2014-15 school year).

114. See H.B. 1625, 92d Gen. Assemb., Reg. Sess. (Ark. 2019) (proposing a criminal defense for "[e]ncouraging the suicide of another person"); see also Bill to Criminalize Encouraging Suicide Advances in Arkansas Legislature, FOX16.COM (Mar. 14, 2019), https://www.fox 16.com/news/local-news/bill-to-criminalize-encouraging-suicide-advancesin-arkansas-legislature/1850426129 (noting that the sponsor of the Arkansas bill said that "he started working on this proposal after reading about the suicide of an 18-year-old Massachusetts boy. His girlfriend repeatedly encouraged him to go through with a suicide attempt. She was later convicted of involuntary manslaughter in a highly publicized trial"). 
$* * *$ 